Technological University Dublin

DÜBLIN

ARROW@TU Dublin

2007-01-01

\title{
In Vitro Toxicity Evaluation of Single Walled Carbon Nanotubes on Human A549 Lung Cells
}

\author{
Maria Davoren \\ Technological University Dublin \\ Eva Herzog \\ Technological University Dublin \\ Alan Casey \\ Technological University Dublin, alan.casey@tudublin.ie
}

See next page for additional authors

Follow this and additional works at: https://arrow.tudublin.ie/radart

\section{Recommended Citation}

Davboren, Maria et al: In vitro toxicity evaluation of single walled carbon nanotubes on human A549 lung cells. Toxicology in Vitrovol. 21, no. 3, pp. 438-448. doi:10.1016/j.tiv.2006.10.007

This Article is brought to you for free and open access by the Radiation and Environmental Science Centre at ARROW@TU Dublin. It has been accepted for inclusion in Articles by an authorized administrator of ARROW@TU Dublin. For more information, please contact arrow.admin@tudublin.ie, aisling.coyne@tudublin.ie, gerard.connolly@tudublin.ie.

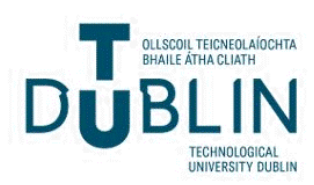




\section{Authors}

Maria Davoren, Eva Herzog, Alan Casey, Benjamin Cottineau, Gordon Chambers, Hugh Byrne, and Fiona Lyng

This article is available at ARROW@TU Dublin: https://arrow.tudublin.ie/radart/2 


\title{
In vitro toxicity evaluation of single walled carbon nanotubes on human A549 lung cells
}

\author{
Maria Davoren ${ }^{\mathrm{a}, *}$, Eva Herzog ${ }^{\mathrm{a}}$, Alan Casey ${ }^{\mathrm{b}}$, Benjamin Cottineau ${ }^{\mathrm{a}, \mathrm{b}}$, Gordon Chambers ${ }^{\mathrm{b}}$, \\ Hugh J. Byrne ${ }^{b}$, Fiona M. Lyng ${ }^{\mathrm{a}}$ \\ a Radiation and Environmental Science Centre, Focas Institute, Dublin Institute of Technology, Kevin Street, Dublin 8, Ireland \\ ${ }^{\mathrm{b}}$ Physics of Molecular Materials Group, Focas Institute, Dublin Institute of Technology, Kevin Street, Dublin 8, Ireland
}

Received 14 June 2006; accepted 15 October 2006

Available online 20 October 2006

\begin{abstract}
This paper describes the in vitro cytotoxicity assessment of single walled carbon nanotubes (SWCNT) on A549 cells, a human lung cell line. Cellular viability was determined using the alamar blue (AB), neutral red (NR) and MTT assays, which evaluated metabolic, lysosomal and mitochondrial activity respectively. In addition, the total protein content of the cells was measured using the coomassie brilliant (CB) blue assay. Supernatants were also assayed for Adenylate Kinase (AK) release and Interleukin 8 (IL-8) which indicated a loss of cell membrane integrity and an inflammation response respectively. To investigate the interactions between serum components in the test medium and the test materials, exposures were conducted both in serum containing (5\%) and serum-free medium. Results from the cytotoxicity tests (AB, CB, MTT) revealed the SWCNT to have very low acute toxicity to the A549 cells as all but one of the reported $24 \mathrm{~h}$ $\mathrm{EC}_{50}$ values exceeded the top concentration tested $(800 \mu \mathrm{g} / \mathrm{ml})$. The SWCNT were found to interfere with a number of the dyes used in the cytotoxicity assessment and we are currently conducting a comprehensive spectroscopic study to further investigate these interactions. Of the multiple cytotoxicity assays used, the AB assay was found to be the most sensitive and reproducible. Transmission electron microscopy (TEM) studies confirmed that there was no intracellular localization of SWCNT in A549 cells following $24 \mathrm{~h}$ exposure; however, increased numbers of surfactant storing lamellar bodies were observed in exposed cells.
\end{abstract}

(C) 2006 Elsevier Ltd. All rights reserved.

Keywords: Single walled carbon nanotubes; Cytotoxicity; TEM; Foetal bovine serum; Lamellar bodies

\section{Introduction}

Nanotechnology is widely perceived as one of the key technologies of the 21st century and accordingly there have been huge advances and increased funding in global technological research on nanomaterials. Single wall carbon nanotubes (SWCNT) are considered to have extensive commercial application potential due to their excellent mechanical, electrical and magnetic properties (Paradise and Goswami, in press). The broad range of increasing nanotechnology applications for SWCNT will almost cer-

\footnotetext{
* Corresponding author. Fax: +35314027904.

E-mail address: maria.davoren@dit.ie (M. Davoren).
}

tainly result in the increased potential for both human and environmental exposures to this nanomaterial. It is, therefore, imperative that toxicological research to evaluate the biocompatibility and possible adverse effects on both the health of humans and the environment is conducted concomitantly with technological research and development on nanomaterials (Dreher, 2004; Oberdörster et al., 2005; Thomas and Sayre, 2005).

Due to their size, SWCNT can easily become airborne and inhaled, hence the evaluation of their pulmonary effects has received a considerable amount of interest and a number of in vivo and in vitro studies have been performed to date. Several studies on the effects of both refined and raw CNT on the lung tissue of various animal models have been reported and there appears to be some inconsistency 
between the research findings (Huczko et al., 2001; Lam et al., 2004; Shvedova et al., 2005; Warheit et al., 2004). These studies highlighted the inherent difficulty in testing CNT due to their agglomerative nature in aqueous solutions; indeed some of the observed mortality was attributed to mechanical blockage of the airways resulting in asphyxiation (Warheit et al., 2004). It is now recognised that in order to elucidate the mechanisms of the pulmonary toxicity observed in these preliminary studies further more realistic in vivo inhalation studies with aerosolised SWCNT need to be conducted (Muller et al., 2006; Smart et al., 2006; Warheit, 2006).

A number of in vitro studies have also been performed on SWCNT with varying metal content and have evaluated different mechanistic endpoints. Shvedova et al. (2003) tested iron-rich (30 wt.\% iron) SWCNT on human epidermal keratinocytes $(\mathrm{HaCaT})$ and following $18 \mathrm{~h}$ exposure reported oxidative stress and loss of cell viability. They also observed that exposure resulted in ultrastructural and morphological changes in these skin cells. Recently, Kagan et al. (2006) demonstrated that iron-rich SWCNT (26wt.\% iron) resulted in a significant loss of intracellular low molecular weight thiols (GSH) and accumulation of lipid hydroperoxides in murine macrophages. Fiorito et al. (2006) investigated the effects of highly purified fullerenes and SWCNT on murine and human macrophages and found these materials did not stimulate the release of the inflammatory marker nitric oxide by murine macrophage cells in culture. In addition, they also demonstrated the uptake of each material by human macrophages to be very low and that each possessed a very low toxicity against human macrophage cells. Jia et al. (2005) exposed SWCNT (with trace amounts of metal catalysts) to alveolar macrophages isolated from guinea pigs for $6 \mathrm{~h}$ and found that the SWCNT elicited a more toxic response than multi walled CNT (MWCNT), quartz and fullerene. SWCNT have also been tested on human embryo kidney cells (HEK293) and were found to inhibit the proliferation of these cells by inducing cell apoptosis and decreasing cellular adhesive ability (Cui et al., 2005). As with the in vivo studies discussed earlier, differences in SWCNT toxicity and biocompatibility have also been observed with the various in vitro tests and these discrepancies can most likely be attributed to the varying percentages of catalysts and other impurities in the tested SWCNT, in addition to the different dispersion methods employed to date (Smart et al., 2006).

The objective of this study was to perform a comprehensive in vitro cytotoxicity assessment of SWCNT (10 wt.\% iron) on A549 cells, a human epithelial-like lung cell line. Quartz was tested in parallel exposures to provide a benchmark of particle toxicity. As we have recently found that there was significant interaction between the SWCNT and foetal bovine serum (FBS) present in the test medium (Casey et al., in press), particle exposures were conducted both in serum containing $(5 \%)$ and serum-free cell culture medium. Cytotoxicity parameters evaluated in this study, following $24 \mathrm{~h}$ exposure to both materials included the met- abolic, lysosomal, and mitochondrial activities of the cells. In addition total protein content, cell membrane integrity and inflammation responses were also measured. The present study also employed TEM to characterise the SWCNT pre exposure, to investigate if the SWCNT were internalised by these lung cells and to examine for any ultrastructural changes in cell morphology post exposure.

\section{Materials and methods}

\subsection{Test materials}

$\mathrm{HiPco}^{\circledR}$ derived SWCNT were purchased from Carbon Nanotechnologies, Inc. (Houston, TX). This material contained $10 \mathrm{wt} . \%$ iron. The diameter distribution of these $\mathrm{HiPco}^{\circledR}$ tubes was previously determined to be $0.8-1.2 \mathrm{~nm}$ by Raman spectroscopy conducted in our laboratory (Gregan et al., 2003). Quartz powder (Certified Reference Material, BCR No. 66) with a particle distribution of 0.35$3.50 \mu \mathrm{m}$ was employed as a positive control and obtained from Sigma Aldrich Ltd. (Dublin, Ireland). This standard quartz sample was mined in Frechen, Germany and is mostly silicon dioxide with trace amounts of iron $\left(0.4 \mathrm{mg} \mathrm{g}^{-1}\right)$, titanium $\left(0.26 \mathrm{mg} \mathrm{g}^{-1}\right)$, sodium $\left(0.09 \mathrm{mg} \mathrm{g}^{-1}\right)$ and calcium $\left(0.06 \mathrm{mgg}^{-1}\right)$.

\subsection{Reagents}

3-(4,5-dimethylthiazol-2-yl)-2,5-diphenyltetrazolium bromide (MTT), Coomassie Brilliant Blue 250 (CB) and Neutral Red (NR) were all purchased from Sigma Aldrich Ltd. (Dublin, Ireland). The ToxiLight ${ }^{\mathrm{TM}}$ kit for Adenylate Kinase (AK) analysis was purchased from Cambrex BioScience (Wokingham Ltd., UK). Alamar Blue ${ }^{\mathrm{TM}}(\mathrm{AB})$ and the Human Interleukin 8 (IL-8) CytoSet $^{\mathrm{TM}}$ were purchased from Biosource (UK). Cell culture media and supplements and the trypsinisation solution were purchased from Biosciences (Dublin, Ireland).

\subsection{Cell culture}

A549 cells (ATCC, CCL-185) a human lung carcinoma epithelial cell line were employed for testing. Cells were cultured in Kaighn's medium (F12K) with $2 \mathrm{mM}$ L-glutamine supplemented with $10 \%$ foetal bovine serum (FBS) and $45 \mathrm{IU} \mathrm{ml}^{-1}$ penicillin and $45 \mu \mathrm{g} \mathrm{ml}^{-1}$ streptomycin at $37^{\circ} \mathrm{C}$ in $5 \% \mathrm{CO}_{2}$ humidified incubator.

\subsection{Dispersion of nanomaterials}

Stock suspensions of SWCNT and quartz were prepared both in serum containing $(5 \%)$ and serum-free $(0 \%)$ medium. An ultrasonic tip (Ultra sonic processor VCX$750 \mathrm{~W}$ ) at amplitude of $40 \%$ for a total time of $30 \mathrm{~s}$ carried out in $10 \mathrm{~s}$ sequential steps was employed to disperse the suspensions prior to preparation of test concentrations. The suspensions were prepared by dispersing an initial 
concentration of $800 \mu \mathrm{g} / \mathrm{ml}$ of each material by sonication. Each stock concentration was then serially diluted on the 96-well plate with each type of medium to prepare test concentrations. Cells were then exposed to the same concentration range of SWCNT and quartz $(1.56,3.12,6.25,12.5,25$, $50,100,200,400,800 \mu \mathrm{g} / \mathrm{ml})$ prepared in both $5 \%-\mathrm{F} 12 \mathrm{~K}$ and $0 \%-\mathrm{F} 12 \mathrm{~K}$ medium. Transmission electron microscopy (TEM) was performed using a Jeol 100CX TEM, on raw as purchased $\mathrm{HiPco}^{\circledR}$ SWCNT by dispersing $1 \mathrm{mg}$ of SWCNT in $10 \mathrm{ml}$ ethanol with the aid of a sonic tip, the dispersion was then dropcast onto $200 \mathrm{~nm}$ formvar coated copper grids for examination.

\subsubsection{Cytotoxicity assays}

For cytotoxicity assays cells were seeded in 96-well microplates (Nunc, Denmark) at a density of $1 \times 10^{5}$ cells/ $\mathrm{ml}$ in $100 \mu \mathrm{F} 12 \mathrm{~K}$ medium containing $10 \% \mathrm{FBS}$. After $24 \mathrm{~h}$ of cell attachment, plates were washed with $100 \mu \mathrm{l} /$ well phosphate buffered saline (PBS) and the cells were treated with increasing concentrations of each nanomaterial prepared in either $5 \%$ or $0 \%$ FBS containing medium for $24 \mathrm{~h}$. Six replicate wells were used for each control and test concentration per microplate. Cytotoxicity was assessed using five assays as outlined below.

\subsection{Alamar blue, neutral red, coomassie blue assays}

The $\mathrm{AB}, \mathrm{NR}$ and $\mathrm{CB}$ assays were conducted subsequently on the same set of plates. The AB assay was performed first. The bioassay was carried out according to manufacturer's instructions. Briefly, control media or test exposures were removed; the cells were rinsed with PBS and $100 \mu \mathrm{l}$ of an $\mathrm{AB} / \mathrm{NR}$ medium $(5 \%[\mathrm{v} / \mathrm{v}]$ solution of $\mathrm{AB}$ and $1.25 \%$ [v/v] of NR dye) prepared in fresh media (without FBS or supplements) were added to each well. Following $3 \mathrm{~h}$ incubation, $\mathrm{AB}$ fluorescence was quantified at the respective excitation and emission wavelength of 540 and $595 \mathrm{~nm}$. Wells containing medium and AB without cells were used as blanks. The mean fluorescent units for the six replicate cultures were calculated for each exposure treatment and the mean blank value was subtracted from these. Viability and protein determination of the cells following exposure to each chemical were then subsequently investigated using the NR and CB assays according to Liebsch and Spielmann (1995) with the modification of Coomassie Brilliant Blue dye being employed in place of Kenacid Blue $\mathrm{R}$ dye.

\subsection{MTT assay}

A second series of plates were set up for the MTT assay. These plates were seeded and exposed identically to the first series of plates prepared for the $\mathrm{AB}, \mathrm{NR}$, and $\mathrm{CB}$ assays. Following $24 \mathrm{~h}$ of nanomaterial exposure, control medium or test exposures were removed (medium from each control/treatment was pooled and frozen at $-80^{\circ} \mathrm{C}$ for subsequent AK and IL-8 analysis), the cells were rinsed with PBS and $100 \mu \mathrm{l}$ of fresh medium (without FBS or supplements) was added to each well. Ten microlitres of MTT $(5 \mathrm{mg} / \mathrm{ml})$ prepared in PBS was then added to each well and the plates were incubated for $3 \mathrm{~h}$ at $37^{\circ} \mathrm{C}$ in a $5 \% \mathrm{CO}_{2}$ humidified incubator. After this incubation period the medium was discarded, the cells were washed with $100 \mu \mathrm{l}$ of PBS and $100 \mu \mathrm{l}$ of DMSO was added to each well to extract the dye. The plate was shaken at $240 \mathrm{rpm}$ for $10 \mathrm{~min}$ and the absorbance was measured at $570 \mathrm{~nm}$.

\subsection{Measurement of Adenylate Kinase ( $A K$ ) release}

The bioluminescent ToxiLight ${ }^{\mathrm{TM}}$ kit (Cambrex BioScience Wokingham Ltd., UK) was employed to measure the concentration of AK present in the supernatants collected as described above. This kit quantitatively measures the release of AK from damaged cells and the assay was performed according to manufacturer's instructions.

\subsection{Measurement of Interleukin-8 (IL-8)}

Medium was assayed in triplicate for IL-8 using an enzyme-linked immunosorbent assay (ELISA) cytoset kit according to manufacturer's instructions (Biosource International, Camarillo, CA).

\subsection{Light and transmission electron microscopy}

Exposures were conducted in $35 \mathrm{~mm}$ petri dishes (Nunc, Denmark) that were seeded with $2 \mathrm{ml}$ of cell suspension prepared in $10 \%$-F $12 \mathrm{~K}$ at a density of $2 \times 10^{5}$ cells $/ \mathrm{ml}$. Cells were allowed to attach for $24 \mathrm{~h}$ and were then exposed to selected concentrations of SWCNT $(0,400,800 \mu \mathrm{g} / \mathrm{ml})$ and quartz $(0,400,800 \mu \mathrm{g} / \mathrm{ml})$ prepared in both $5 \%$-F $12 \mathrm{~K}$ and $0 \%-\mathrm{F} 12 \mathrm{~K}$ medium for $24 \mathrm{~h}$. Following exposures, cells were washed with $0.1 \mathrm{M}$ phosphate buffer and then fixed in $2.5 \%$ glutaraldehyde in $0.1 \mathrm{M}$ phosphate buffer for $1 \mathrm{~h}$, post-fixed in $1 \% \mathrm{OsO}_{4}$ in $0.1 \mathrm{M}$ phosphate buffer for a further hour, dehydrated in ascending grades of ethanol and subsequently embedded in epoxy resin. Light microscopy sections $(1 \mu \mathrm{m})$ were cut en face with a glass knife, stained with $1 \%$ toluidine blue and mounted with DPX. These sections were examined using a Nikon Eclipse E600 microscope and images were recorded using a Spot RT digital camera. Ultra thin sections $(80 \mathrm{~nm})$ were cut en face with a diamond knife, stained with uranyl acetate and lead citrate and examined using an FEI Tecnai $\mathrm{G}^{2}$ TEM.

\subsection{Statistics}

Fluorescence as fluorescent units (FUs), luminescence as relative light units (RLUs) and absorbance were all quantified using a microplate reader (TECAN GENios, Grödig, Austria). Experiments were conducted in at least triplicate (three independent experiments). Test treatments for each assay (AB, NR, MTT, CB) were expressed as percentage of the unexposed control \pm standard deviation (SD). Control 
values were set at $100 \%$. For the AK assay, cytotoxicity was expressed as mean percentage increase relative to the unexposed control \pm SD. Control values were set at $0 \%$ cytotoxicity. Cytotoxicity data (where appropriate) was fitted to a sigmoidal curve and a four parameter logistic model used to calculate the $50 \%$ Effective Concentration $\left(\mathrm{EC}_{50}\right)$, which was the concentration of nanomaterial which caused a $50 \%$ inhibition in comparison to untreated controls. The $\mathrm{EC}_{50}$ values are reported $\pm 95 \%$ Confidence Intervals $( \pm 95 \% \mathrm{CI})$. This analysis was performed using Xlfit3 ${ }^{\mathrm{TM}}$ a curve fitting add-in for Microsoft ${ }^{\circledR}$ Excel (ID Business Solutions, UK). For cytokine analysis the IL-8 concentration $(\mathrm{pg} / \mathrm{ml})$ for each treatment was calculated from a standard curve conducted in parallel with test samples. Coefficient of variation (CV) for the controls of each test was calculated to ascertain reproducibility. Statistical analyses were carried out using one-way analyses of variance (ANOVA) followed by Dunnett's multiple comparison test.

\section{Results}

\subsection{Initial characterisation of $S W C N T$}

The TEM images obtained for $\mathrm{HiPco}^{\circledR}$ nanotubes (as purchased) tested in this study are shown in Fig. 1. Fig. 1A shows an area of what is termed high density tubes, bundles/aggregates of varying lengths and diameters can be clearly seen which is typical of raw HiPco ${ }^{\circledR}$ SWCNT. In Fig 1B, individual SWCNT and remnant catalytic iron particles resultant from the fabrication process are evident.

\subsection{Alamar blue assay}

Significant cytotoxicity $(P \leqslant 0.05)$ was recorded at 400 and $800 \mu \mathrm{g} / \mathrm{ml} \mathrm{SWCNT}$ tested in the presence of serum for the $\mathrm{AB}$ assay, with approximately $33 \%$ and $53 \%$ inhibition demonstrated respectively in comparison to untreated controls. The $\mathrm{EC}_{50} \pm 95 \% \mathrm{CI}$ value was determined as $744 \pm$ $91 \mu \mathrm{g} / \mathrm{ml} \mathrm{SWCNT}$ for serum exposures. In serum free media significant cytotoxicity was again recorded at 400 and
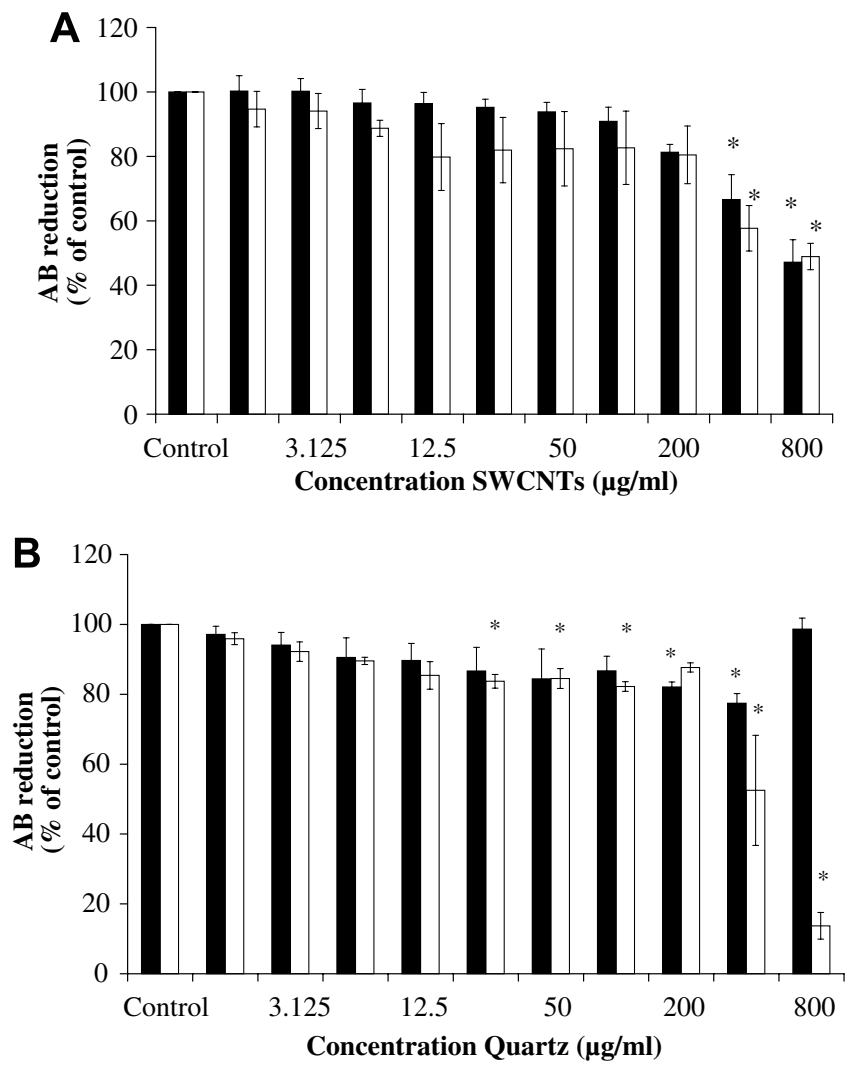

Fig. 2. Cytotoxicity of SWCNT (A) and quartz (B) to A549 cells after $24 \mathrm{~h}$ exposure determined by the $\mathrm{AB}$ assay. Exposures were conducted in media containing $5 \%$ serum $(\boldsymbol{\square})$, and serum free media $(\square)$. Data are expressed as percent of control mean $\pm \mathrm{SD}$ of three independent experiments. ${ }^{*}$ Denotes a significant difference from the control $(P \leqslant 0.05)$. CV for the controls ranged from $1.7 \%$ to $28.7 \%$ in serum containing media and $2.7-22.9 \%$ in serum free media for the SWCNT and $2.1-4.7 \%$ in serum containing media and in $2.9-3.7 \%$ in serum free media for quartz.

$800 \mu \mathrm{g} / \mathrm{ml}$ SWCNT where a $42 \%$ and $51 \%$ inhibition in AB fluorescence was recorded in comparison to unexposed controls (Fig. 2A). In the absence of serum, the $\mathrm{EC}_{50}$ was found to be $>800 \mu \mathrm{g} / \mathrm{ml}$ SWCNT.

Following exposure of the A549 cells to quartz in serum containing medium significant cytotoxicity was observed at
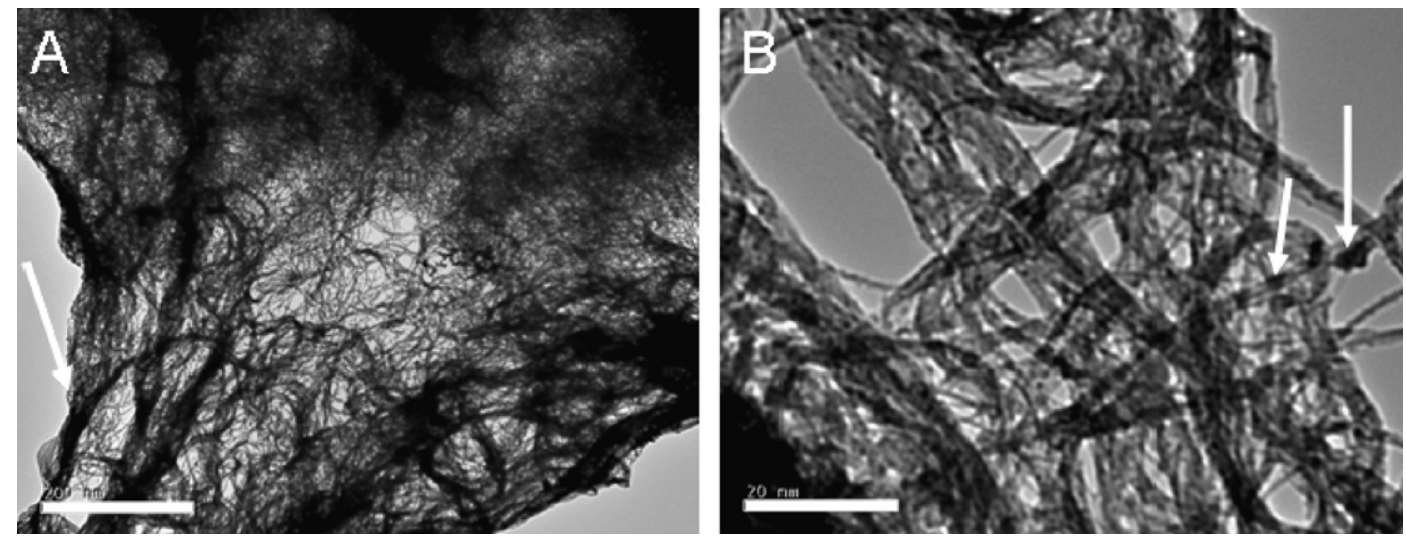

Fig. 1. TEM of HiPco ${ }^{\circledR}$ SWCNT (as purchased) (A) 20,000 $\times$ magnification showing large aggregates (arrows) and high density tubes (B) $200,000 \times$ magnification showing remnant catalytic iron particles (arrows). 
200 and $400 \mu \mathrm{g} / \mathrm{ml}$, which resulted in an $18 \%$ and $23 \%$ inhibitory effect respectively in comparison to controls. At the top concentration tested $(800 \mu \mathrm{g} / \mathrm{ml})$, however, only a $2 \%$ inhibition was recorded in comparison to untreated controls, hence no $\mathrm{EC}_{50}$ value was derived for this exposure. For quartz exposures in the absence of serum significant cytotoxicity was observed at $25,50,100,400$, and $800 \mu \mathrm{g} / \mathrm{ml}$. Approximately $50 \%$ and $90 \%$ inhibition was recorded in comparison to untreated controls at 400 and $800 \mu \mathrm{g} / \mathrm{ml}$ quartz respectively (Fig. 2B). An $\mathrm{EC}_{50}$ of $397 \pm 159 \mu \mathrm{g} / \mathrm{ml}$ for quartz exposure without serum was determined.

\subsection{Coomassie blue assay}

SWCNT in serum containing medium produced significant cytotoxicity at concentrations of 400 (25\% inhibition) and 800 (32\% inhibition) $\mu \mathrm{g} / \mathrm{ml}$, as elucidated using the CB assay. In the absence of serum, significant cytotoxicity was also observed at these concentrations (Fig. 3A). No $\mathrm{EC}_{50}$ values were determined for the $\mathrm{CB}$ assay for both serum and serum free exposures, as maximum cytotoxicity determined in both instances was less than $50 \%$.
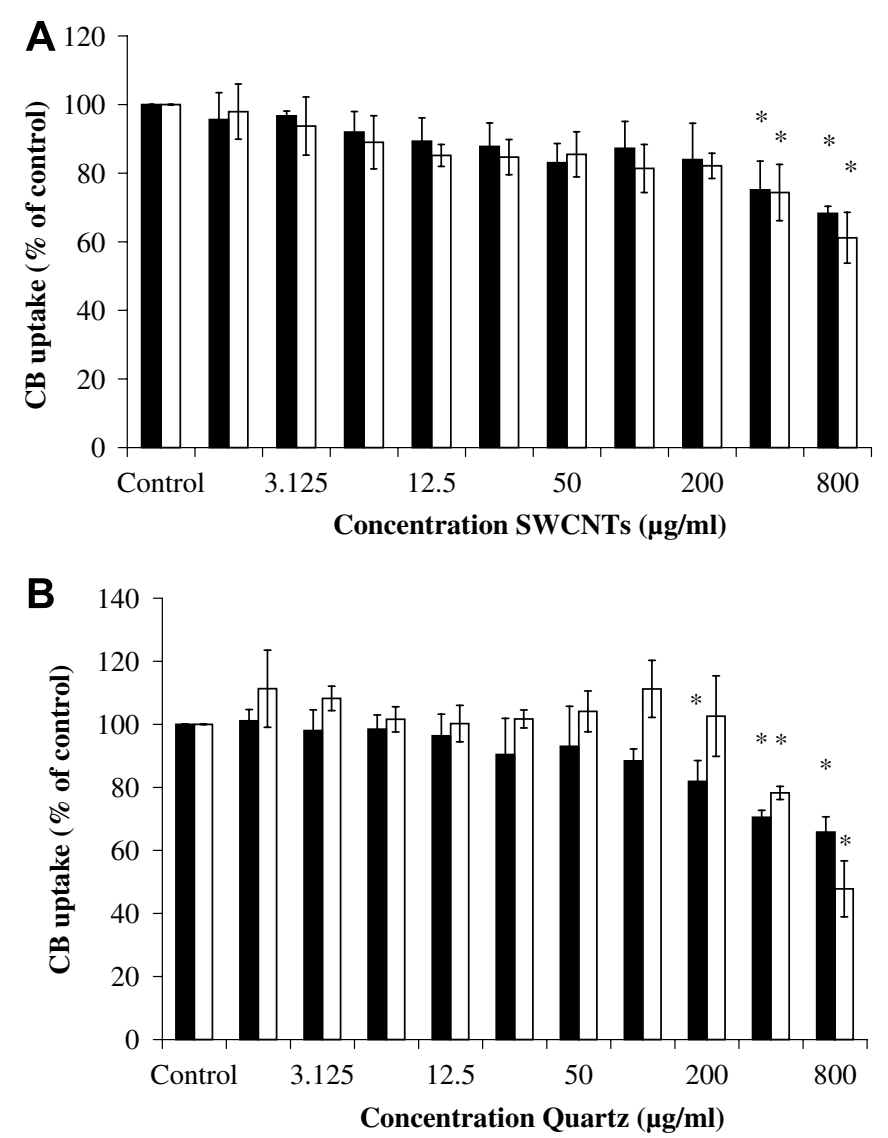

Fig. 3. Cytotoxicity of SWCNT (A) and quartz (B) to A549 cells after $24 \mathrm{~h}$ exposure determined by the $\mathrm{CB}$ assay. Exposures were conducted in media containing 5\% serum (ם), and serum free media $(\square)$. Data are expressed as percent of control mean $\pm \mathrm{SD}$ of three independent experiments. ${ }^{*}$ Denotes a significant difference from the control $(P \leqslant 0.05)$. CV for the controls ranged from $6.1 \%$ to $14.5 \%$ in serum containing media and $3.6-$ $25.2 \%$ in serum free media for the SWCNT and $4.4-6.3 \%$ in serum containing media and in $13.2-20.8 \%$ in serum free media for quartz.
For quartz exposures in serum containing media, significant cytotoxicity was determined at 200,400 and $800 \mu \mathrm{g} / \mathrm{ml}$, with approximately $18 \%, 30 \%$ and $34 \%$ inhibition compared to untreated controls recorded respectively. Therefore the $\mathrm{EC}_{50}$ value was greater than the top concentration tested. In the absence of serum, a slight but non-significant increase in $\mathrm{CB}$ absorbance over controls was recorded for concentrations up to and including $200 \mu \mathrm{g} / \mathrm{ml}$ quartz. Significant cytotoxicity was recorded at 400 (22\% inhibition) and 800 (52\% inhibition) $\mu \mathrm{g} / \mathrm{ml}$ quartz (Fig. 3B). An $\mathrm{EC}_{50}$ of $753 \pm 187 \mu \mathrm{g} / \mathrm{ml}$ for quartz exposure without serum was determined with this assay.

\subsection{MTT assay}

For the MTT assay, exposure in serum containing media resulted in significant cytotoxicity from $12.5 \mu \mathrm{g} / \mathrm{ml} \mathrm{SWCNT}$ upwards, and a maximum of $32 \%$ inhibition was recorded at $800 \mu \mathrm{g} / \mathrm{ml} \mathrm{SWCNT} \mathrm{in} \mathrm{comparison} \mathrm{to} \mathrm{the} \mathrm{control.} \mathrm{For}$ exposures in the absence of serum, significant cytotoxicity was recorded from $3.125 \mu \mathrm{g} / \mathrm{ml}$ SWCNT upwards and $800 \mu \mathrm{g} / \mathrm{ml} \mathrm{SWCNT}$ resulted in approximately $45 \%$ inhibition in comparison to the control (Fig. 4A). No $\mathrm{EC}_{50}$ values were, therefore, determined for the MTT assay for both serum and serum free exposures to SWCNT, as maximum cytotoxicity determined in both instances was less than $50 \%$.

No significant cytotoxicity was determined following $24 \mathrm{~h}$ exposure of the A549 cells to quartz in serum containing media. For the majority of the concentrations tested (except $400 \mu \mathrm{g} / \mathrm{ml}$ ) a stimulatory or hormetic response was recorded but none of these were found to be statistically significant when compared to untreated controls. In the absence of serum in the test medium, significant cytotoxicity was determined at 100, 400 and $800 \mu \mathrm{g} / \mathrm{ml}$ quartz, with approximately $80 \%$ inhibition recorded at the top concentration (Fig. 4B). An $\mathrm{EC}_{50}$ of $465 \pm 130 \mu \mathrm{g} / \mathrm{ml}$ for quartz exposure without serum was determined with the MTT assay.

\subsection{Light and transmission electron microscopy}

\subsubsection{Cellular uptake of SWCNT}

No evidence of SWCNT internalisation (either in serum containing or serum free media) was found for this lung epithelium model. Due to the crystalline nature of quartz it was not possible to section the exposed cell cultures for subsequent TEM imaging.

\subsubsection{Cellular morphology post exposure to $S W C N T$}

Light micrographs of the A549 cells following exposure to selected concentrations of SWCNT and quartz in serum containing medium are presented in Fig. 5. Control A549 cells were of typical cuboidal shape, indicative of type II pulmonary morphology (Fig. 5A). Cells exposed to SWCNT exhibited altered morphology and necrotic and apoptotic cells were observed (Fig. 5B and C). Exposure to the positive 

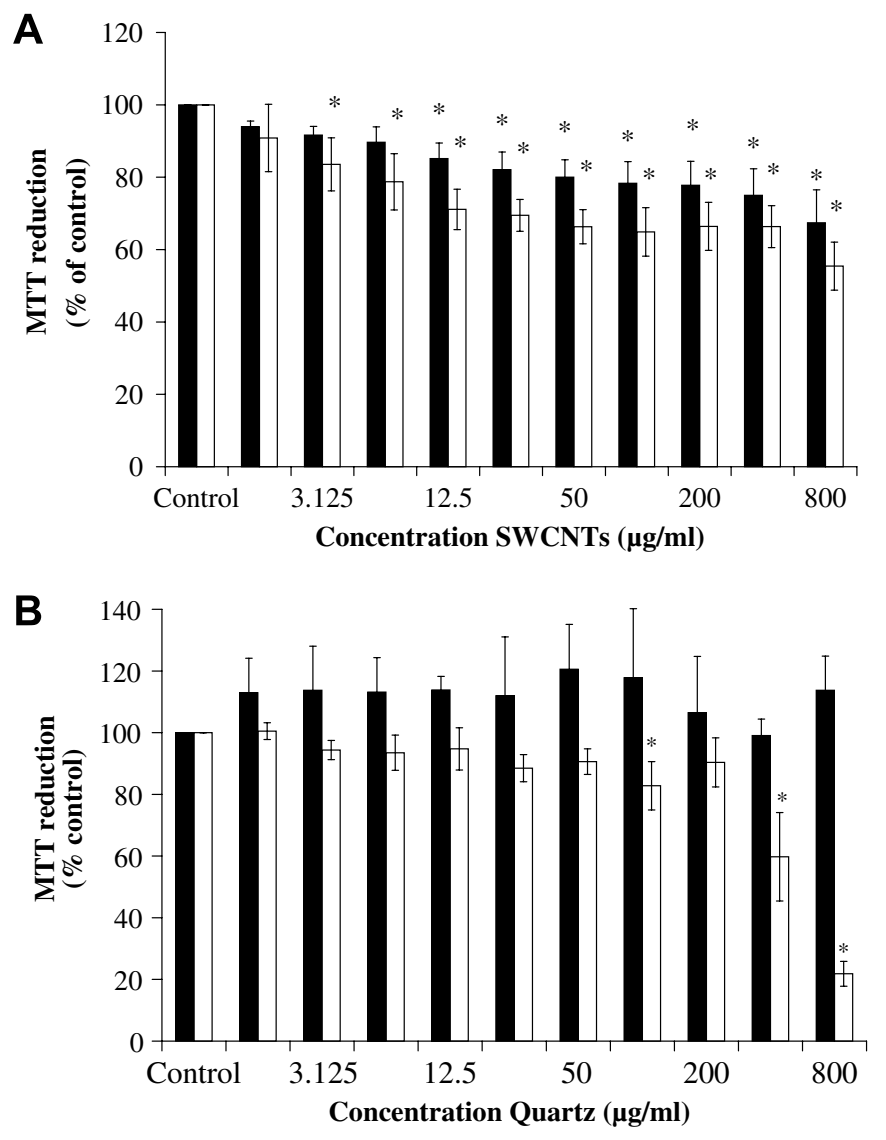

Fig. 4. Cytotoxicity of SWCNT (A) and quartz (B) to A549 cells after $24 \mathrm{~h}$ exposure determined by the MTT assay. Exposures were conducted in media containing $5 \%$ serum $(\square)$, and serum free media $(\square)$. Data are expressed as percent of control mean $\pm \mathrm{SD}$ of four (SWCNT) or three (quartz) independent experiments. * Denotes a significant difference from the control $(P \leqslant 0.05)$. CV for the controls ranged from $3.8 \%$ to $12.1 \%$ in serum containing media and $0.3-23.1 \%$ in serum free media for the SWCNT and $5.5-15.3 \%$ in serum containing media and in $4.6-9.1 \%$ in serum free media for quartz.

control quartz $(800 \mu \mathrm{g} / \mathrm{ml})$ resulted in extensive cell mortality as evidenced by the cell debris seen in Fig. 5D.

Morphological features such as lamellar body structures, microvilli, tonofilaments, desmosome junctions, characteristic of alveolar epithelial type II (AE2) cells were observed in TEM images of control cell cultures (Fig. 6). Following exposure to $400 \mu \mathrm{g} / \mathrm{ml}$ SWCNT, an increase in lamellar bodies was recorded (Fig. 7A-C); multivesicular bodies were also observed (Fig. 7B) and the presence of extracellular (excreted) lamellar bodies was noted (Fig. 7C). Following exposure to the highest test concentration of SWCNT, we observed substantially more lamellar bodies when compared to untreated controls, although this observation was not quantified (Fig. 7D-E). A reduction in microvilli and an increase in lipid droplet numbers were also evident compared to control cultures. Multivesicular bodies were also observed at the cell surface (Fig. 7F).

One of the main problems encountered in the investigation of SWCNT cytotoxicity is the tendency of these nanoparticles to aggregate into large bundles. A phase contrast micrograph of A549 cells following $24 \mathrm{~h}$ exposure to $800 \mu \mathrm{g} /$ $\mathrm{ml}$ SWCNT reveals large aggregates on the cell surface (Fig. 8). These aggregates remained adhered to the cell surface even after several washes with PBS.

\section{Discussion}

This paper describes a comprehensive in vitro cytotoxicity assessment of SWCNT on A549 cells, a human lung carcinoma epithelial cell line. Quartz was tested in parallel exposures to provide a benchmark of particle toxicity. Parameters evaluated in this study following $24 \mathrm{~h}$ exposure to both materials, included the metabolic, lysosomal, and mitochondrial activities, in addition to total protein content, cell membrane integrity and inflammation response. The present study also employed TEM to characterise the samples pre exposure, to investigate if the SWCNT were internalised by these lung cells and to examine for any ultrastructural changes in cell morphology post exposure.

The pathogenicity of quartz has been well documented both in vitro and in vivo pulmonary studies; hence, it is routinely employed as a positive control to benchmark particle toxicity (Diabeté et al., 2002; Lam et al., 2004; Warheit et al., 2004). In cytotoxicity tests with quartz (AB, NR, CB, MTT), we observed marked differences between the toxicity elicited in the presence and absence of serum. For all four endpoints, the presence of serum had a substantial attenuation on the cytotoxicity of quartz and the $\mathrm{EC}_{50}$ values in all assays were found to be $>800 \mu \mathrm{g} / \mathrm{ml}$ quartz. In the absence of serum, however, significant cytotoxicity was demonstrated for all endpoints and the rank order of endpoint sensitivity based on calculated $\mathrm{EC}_{50}$ values was $\mathrm{AB}>\mathrm{NR}>\mathrm{MTT}>\mathrm{CB}$. Quartz exposure in serum free media was also found to induce a significant release of AK at both 400 and $800 \mu \mathrm{g} / \mathrm{ml}$, which was indicative of cell membrane damage at these concentrations (data not shown).

Cell cultures are routinely grown and tested in media supplemented with various percentages of serum proteins such as FBS. Gülden and Seibert (2005) have recently reported that the bioavailability of chemicals in vitro can be reduced due to partitioning into lipids and binding to serum proteins. The 'protective' effect of serum in silica toxicity has also been well documented (Emerson and Davis, 1983; Schimmelpfeng et al., 1992). Antonini and Reasor (1994) demonstrated that coating of silica with a commercially available bovine pulmonary surfactant afforded short-term protection against its toxicity when tested both in vitro on rat alveolar macrophages and in vivo following intratracheal instillation. Antonini et al. (1994) also demonstrated that pretreatment of rats with amiodarone, a drug that significantly increases the concentration of total phospholipid in whole lung resulted in reduced toxicity of silica dust following subsequent intratracheal instillation. We are currently investigating the effect of increased exposure time (e.g. 48, 72, 96h) of the cells to both nanomaterials in order to establish if the protective effect of the serum diminishes over time. 

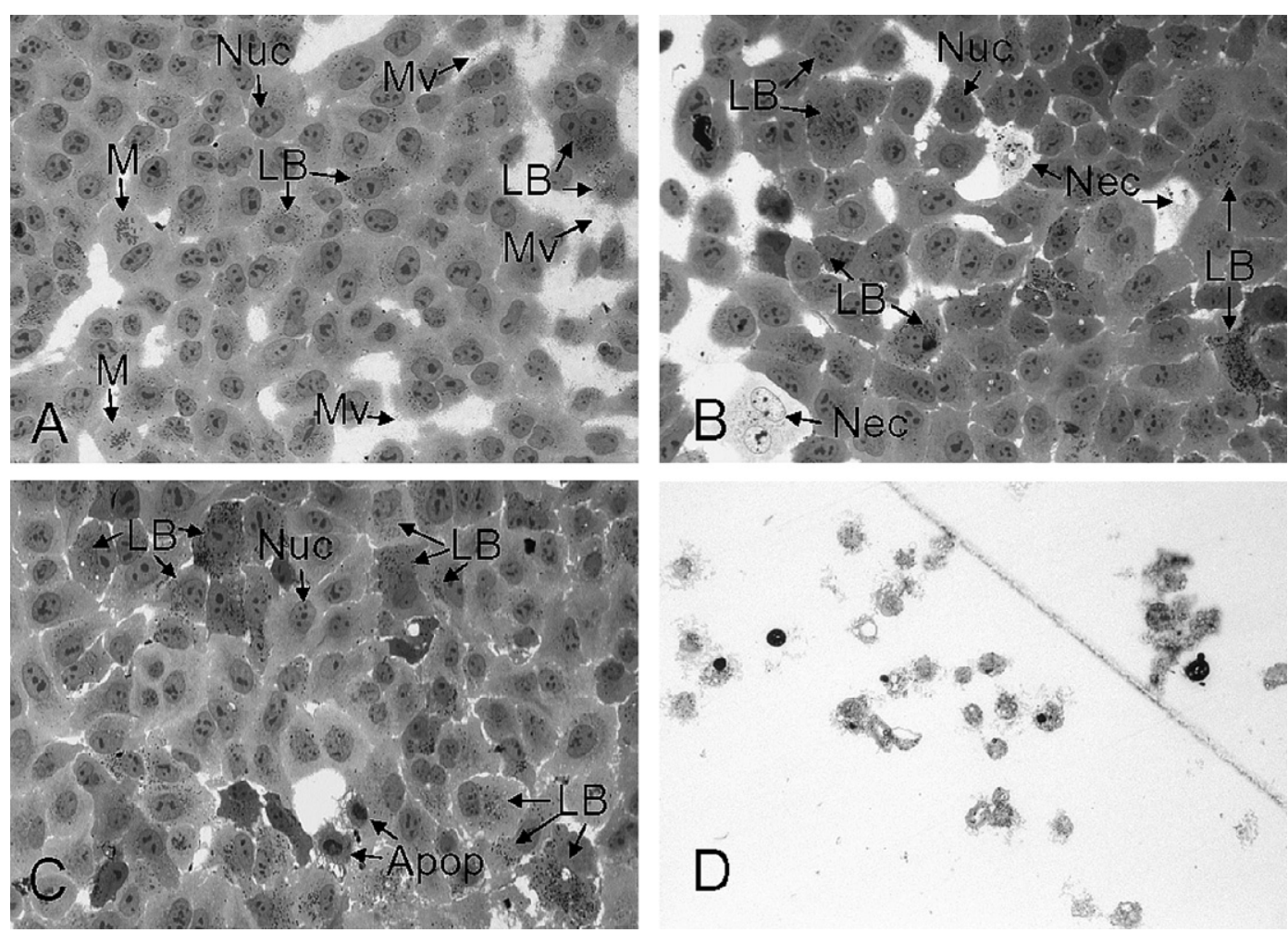

Fig. 5. Light micrographs of A549 (A) control cells showing nucleus (Nuc) and cells in metaphase (M) and lamellar bodies (LB), and microvilli (Mv), (B) cells exposed to $400 \mu \mathrm{g} / \mathrm{ml} \mathrm{SWCNT}$ with serum showing nucleus (Nuc) and necrotic cells (Nec), and lamellar bodies (LB) (C) cells exposed to $800 \mu \mathrm{g} / \mathrm{ml}$ SWCNT with serum showing nucleus (Nuc) and apoptotic cells (Apop) and lamellar bodies (LB) (D) cells exposed to $800 \mu \mathrm{g} / \mathrm{ml}$ quartz showing cell debris. Mag $400 \times$.

From the results obtained for quartz, it can be concluded that cell metabolism (AB assay), and mitochondrial activity (MTT) are negatively impacted at concentrations lower than that required for cell detachment $(\mathrm{CB})$. The $\mathrm{AB}$ assay has also been previously employed to assess the cytotoxicity of SWCNT in human keratinocyte cells (Shvedova et al., 2003). Based on the $\mathrm{EC}_{50}$ values for quartz and the coefficient of variation $(\mathrm{CV})$ values for the controls, this assay was found to be the most sensitive and reproducible (lowest CV values) endpoint employed in the current study.

While conducting the cytotoxicity assays it was observed that the SWCNT were interacting with some of the colorimetric and fluorescent dyes used in the toxicity assessment, resulting in unexpected absorption/fluorescence data. The most obvious interference was found with the NR assay as widely fluctuating results were obtained with this endpoint. Monteiro-Riviere and Inman (2006) have also reported that this viability dye was adsorbed onto carbon and thus found interference with the absorption spectra of the dye resulting in false readings. The adsorbing properties of the carbon nanotubes were also suspected to interfere with the Adenylate Kinase and cytokine assays in the present study hence no results for the NR, AK or IL-8 assay for either the SWCNTs or the positive control quartz were presented. Monteiro-Riviere and Inman (2006) also observed interference with the cytokine assay and postulated that the tested carbon black may have adsorbed the IL- 8 released by the cells in their study. Another recent study has also reported SWCNT interference with the MTT assay (Wörle-Knirsch et al., 2006). Hurt et al. (2006) recently addressed this confounding issue and advised caution when performing even established toxicity assays in the presence of significant quantities of fine carbon.

Results presented for the cytotoxicity tests $(\mathrm{AB}, \mathrm{CB}$, MTT) revealed the SWCNT to have very low acute toxicity to the A549 cells, as all but one of the reported $24 \mathrm{~h} \mathrm{EC} 50$ values exceeded the top concentration tested $(800 \mu \mathrm{g} / \mathrm{ml})$. The AB assay was found to be the most sensitive endpoint as the greatest cytotoxicity (approximately $50 \%$ in both $5 \%$ serum and serum free media) was recorded at the top concentration of SWCNT. However, given the recent reports of interference of the various dye markers and until such time that we can establish/overcome the adsorptive interferences of the SWCNT on the employed dye markers, it is not possible to draw any firm conclusions from these toxicity results. We are therefore currently conducting a full spectroscopic study, namely Raman, UV-vis absorption and fluorescence spectroscopy, to assess the interactions of the SWCNT and the various dye markers employed in this study. It is also worth noting that transformed cell lines are typically less resistant to toxic effects than other cells derived from normal tissues. We are therefore also currently using normal lung cell lines e.g. HFL and BEAS-2B in our on-going toxicity studies. 

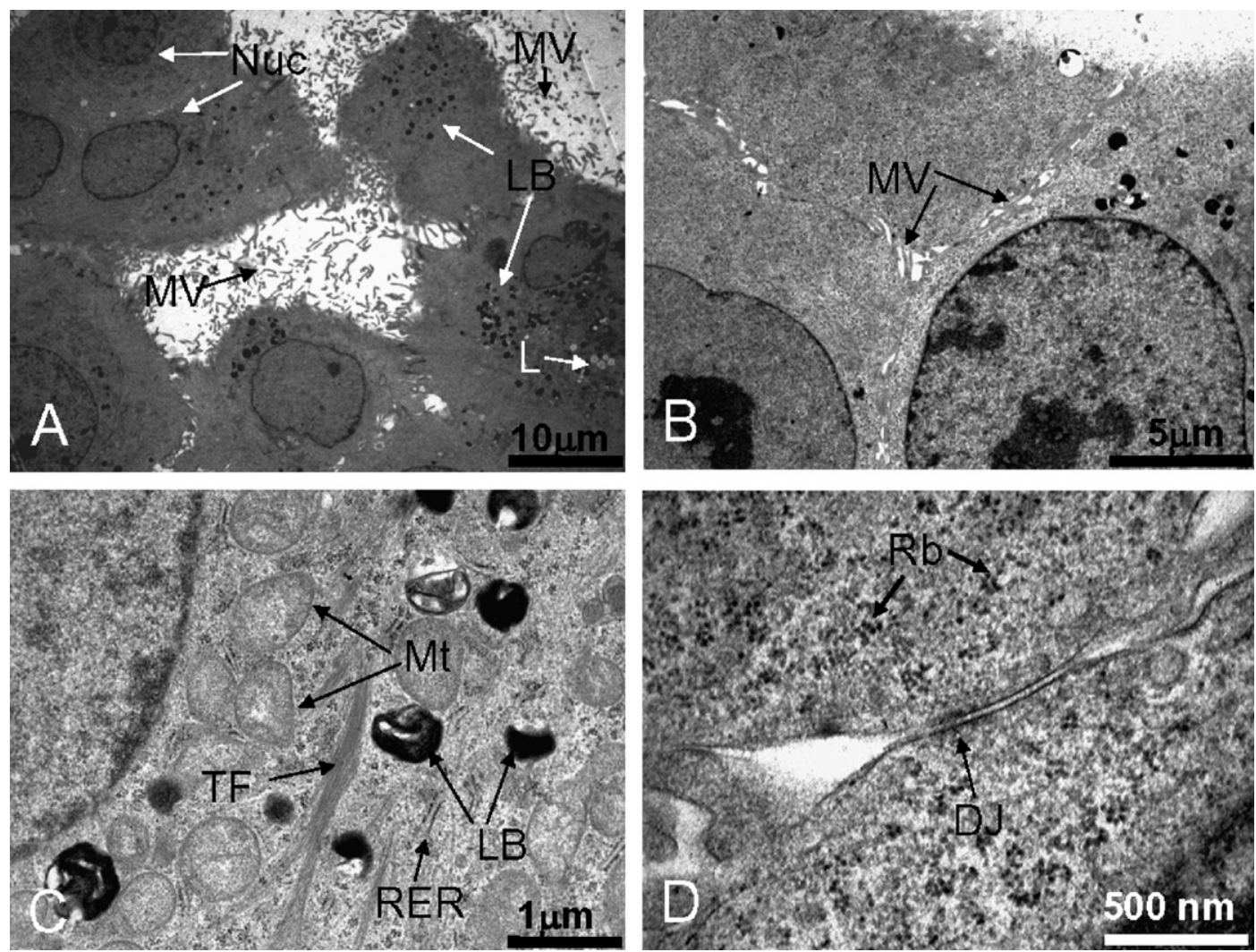

Fig. 6. TEM of A549 control cells showing (A) nucleus (Nuc), lamellar bodies (LB), lipid droplets (L) and extensive microvilli (Mv), (B) intracellular microvilli (Mv), (C) mitochondria (Mt), lamellar bodies (LB), tonofilaments (TF) and rough endoplasmic reticulum (RER), and (D) desmosome junction (DJ) and free ribosomes $(\mathrm{Rb})$
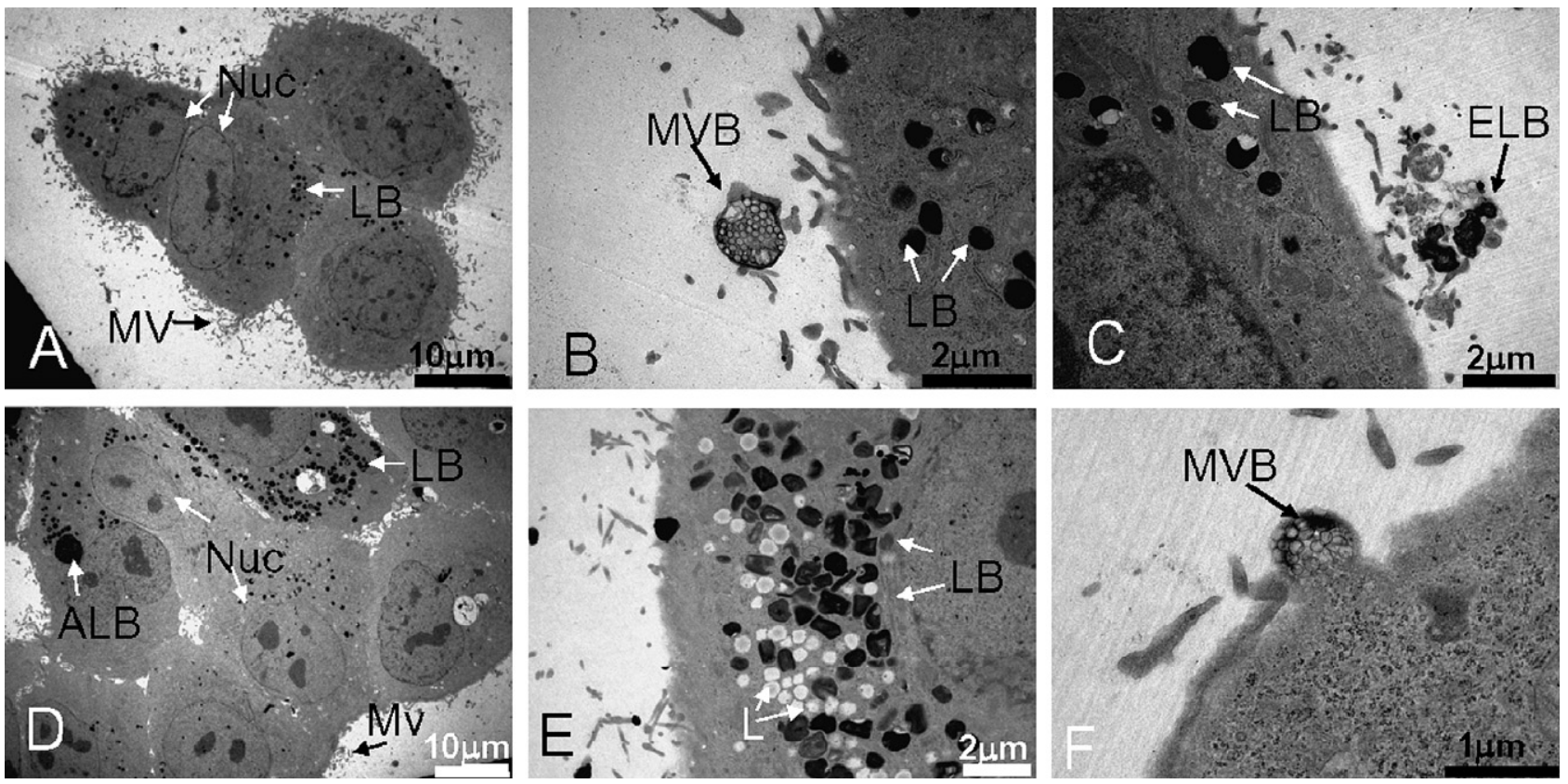

Fig. 7. TEM of A549 cells treated with $400 \mu \mathrm{g} / \mathrm{ml} \mathrm{SWCNT} \mathrm{(A-C)} \mathrm{showing} \mathrm{(A)} \mathrm{nucleus} \mathrm{(Nuc),} \mathrm{lamellar} \mathrm{bodies} \mathrm{(LB),} \mathrm{and} \mathrm{microvilli} \mathrm{(Mv),} \mathrm{(B)} \mathrm{lamellar} \mathrm{bod-}$ ies (LB) and multivesicular body (MVB), (C) lamellar bodies (LB) and extracellular lamellar bodies (ELB) and A549 cells treated with $800 \mu \mathrm{g} / \mathrm{ml} \mathrm{SWCNT}$ (D-F) showing (D) nucleus (Nuc), lamellar bodies (LB), and reduced microvilli (Mv), and an aggregation of lamellar bodies (ALB), (E) lamellar bodies (LB) and an accumulation of lipid droplets (L), (F) a multivesicular body (MVB) associated with the plasma membrane. A549 cells were exposed to SWCNTs either with serum (A, B and D, E) or without serum (C and F). 


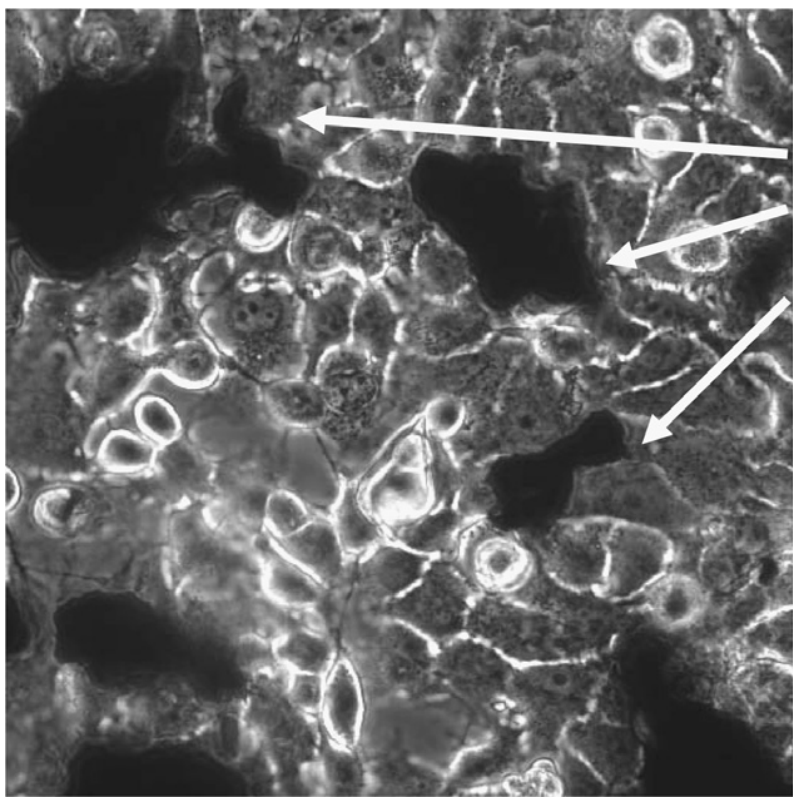

Fig. 8. Phase contrast micrograph $(200 \times)$ of A549 cells following $24 \mathrm{~h}$ exposure to $800 \mu \mathrm{g} / \mathrm{ml}$ SWCNT with $5 \%$ serum showing aggregates (arrows) on cell surface. These aggregates were still observed on the cell surface after several washes with PBS.

One of the main problems in the toxicity evaluation of SWCNT is the propensity of the nanotubes to agglomerate owing to substantial van der Waals attractions. As a means to reduce the formation of such bundles, researchers have employed numerous carrier solvents including media with varying FBS percentages, serum and organic synthetic surfactants. The use of different dispersal solvents will obviously influence the concentration of SWCNT available to the cell and Smart et al. (2006) have recently proposed that discrepancies in toxicity and biocompatibility data may be attributed to the different dispersion methods employed to date. In this study we chose not to employ synthetic surfactants, but rather to investigate the interactions between the FBS routinely used for the culturing and testing of the A549 cells and the SWCNT. Test exposures were therefore conducted both in serum containing $(5 \%)$ and serum-free medium. Visual observation of the SWCNT prior to cell exposure revealed that nanotubes appeared to solubilise (disaggregate) more readily in serum containing medium and indicated that the presence of serum had a dispersion effect on the SWCNT. Monteiro-Riviere et al. (2005) found that different synthetic surfactants showed increased dispersion and reduced aggregation of MWCNT, but they also noted that the presence of surfactant did not alter the cytotoxicity of the MWCNT to a human keratinocyte cell line (HEK) as determined by the NR assay. In this study we found that in general greater toxicity was demonstrated with the SWCNT in the absence of serum (Figs. 3A and 4A). In parallel studies to the in vitro cytotoxicity assessment we also employed spectroscopic techniques to assess the interaction of the SWCNT and the various media components and we found that there was significant interaction between the SWCNT and FBS (Casey et al., in press).

As significant cytotoxicity was demonstrated at 400 and $800 \mu \mathrm{g} / \mathrm{ml}$ of SWCNT with the AB, CB and MTT assays, cells were subsequently exposed to these concentrations for $24 \mathrm{~h}$, and light and transmission electron microscopy were employed to assess for nanomaterial interaction/localisation within the A549 cells and for evidence of dose related morphological changes. Cells were also exposed to the same concentrations of quartz without serum and light microscopy sections confirmed the extensive cell death demonstrated in the viability assays. We found no evidence in this study that this lung epithelium model internalized the SWCNT. Similarly, whilst Shvedova et al. (2003) reported ultrastructural changes in cell morphology of $\mathrm{HaCaT}$ cells, TEM imaging did not reveal intracellular localization of these particles. Other studies have shown that internalization of various nanoparticles can occur. Wörle-Knirsch et al. (2006) recently reported that SWCNT could be found as bundles of thousands inside A549 cells and postulated that they were mostly encapsulated in endosomes and infrequently found inside mitochondria. Monteiro-Riviere et al. (2005) demonstrated MWCNT were primarily located within the intracytoplasmic vacuoles of human epidermal keratincotyes (HEKs) and demonstrated different morphology between control and those exposed to MWCNT. More recently, the same group (Rouse et al., 2006) has reported that fullerene-based amino acid nanoparticles can also localize to intracytoplasmic vacuoles in HEK cells. The internalization of ultrafine titanium dioxide by A549 cells has also been reported (Stearns et al., 2001). In the concurrent spectroscopic study performed by our group (Casey et al., in press) Raman and fluorescence emission analysis indicated that no debundling or reduction in aggregation state occurred upon the dispersion of SWCNT in the media over the concentration range studied. Typically these aggregates can be of the order of microns therefore reducing the likelihood of internalization.

While we did not find any evidence of SWCNT internalization in the A549 cells, we did observe ultrastructural changes in the cell morphology following SWCNT exposure. It is worth noting however, that we could not distinguish any obvious qualitative morphological differences between those exposures conducted with and without serum. The A549 cells have retained the main properties of AE2 cells, i.e. pulmonary surfactant secretory functions (Lieber et al., 1976; Fehrenbach, 2001) and within these cells the lamellar bodies are recognised as storage vessels from which surfactant is released into the alveolus (Askin and Kuhn, 1971). After secretion, alveolar forms of surfactant include these lamellar bodies, highly organised structures termed tubular myelin, and monolayered and multilayered, phospholipid-rich sheets and vesicles (Whitsett and Weaver, 2002). While the principal function of this pulmonary surfactant is the regulation of surface tension in the lungs (Nicholas, 1996), it is also postulated that increased 
production of this surfactant may play a role in defending the lungs against chemical and particulate damage (Hook, 1991, 1993).

Following exposure to both 400 and $800 \mu \mathrm{g} / \mathrm{ml} \mathrm{SWCNT,}$ an increase in lamellar bodies compared to untreated controls was observed within exposed cells. In addition, the presence of extracellular lamellar bodies, which appeared to have exocytosed their contents, was recorded at $400 \mu \mathrm{g} / \mathrm{ml}$ SWCNT (Fig. 7C). Multivesicular bodies were also observed following cell exposure to both 400 and $800 \mu \mathrm{g} / \mathrm{ml} \mathrm{SWCNT \text {. }}$ We surmise that these vesicles were most likely the phospholipid-rich multivesicular bodies as mentioned above, which are involved in the surfactant synthesis and recycling. Interestingly, a very similar plasma membrane projection as that identified by us in Fig. 7F was shown by Stearns et al. (2001), in an electron micrograph following exposure of A549 cells to $40 \mu \mathrm{g} / \mathrm{ml}$ ultrafine titanium dioxide. Stearns et al. (2001) also reported that aggregates of $\mathrm{TiO}_{2}$, which entered the A549 cells by ingestion, were later found in membrane-bound vacuoles and enmeshed within lamellar bodies. Recently, in an in vivo study, Shvedova et al. (2005) also observed increased numbers of AE2 cells expressing cytoplasmic lamellar bodies in TEM sections of mouse lung following SWCNT exposure via pharyngeal aspiration.

We therefore hypothesize that the increased presence of these lamellar bodies and the concurrent surfactant secretion is a protective response of the lung cells to reduce the cytotoxic effects of SWCNT. Hook (1993) postulated that one possible mechanism that might account for the protective effects is the quenching of free radicals by the unsaturated phospholipids of pulmonary surfactant. This theory seems quite plausible considering, as we have previously discussed, surface modification of silica with phospholipids can markedly reduce its toxicity. Previous research has also shown that direct mechanical stretching of the AE2 cells can trigger the release of surfactant (Wirtz and Dobbs, 1990). As can be seen in Fig. 8, SWCNT were found to aggregate on the cell surface and remained attached even after several washes with PBS, hence another possible stimulus for this enhanced secretion of surfactant may be due to the physical stress of the SWCNT aggregates on the cell surface.

In conclusion, exposure of A549 cells to a wide dose range of SWCNT $(1.56-800 \mu \mathrm{g} / \mathrm{ml})$ for $24 \mathrm{~h}$ revealed the SWCNT to have low acute toxicity. In this study we found that in general, greater SWCNT toxicity was observed in the absence of serum, although this trend was not as marked as that observed for quartz exposures. The SWCNT were found to interfere with a number of the dyes used in the cytotoxicity assessment and we are currently conducting a comprehensive spectroscopic study to further investigate these interactions. Of the multiple cytotoxicity assays used, the AB assay was found to be the most sensitive. TEM studies confirmed that there was no intracellular localization of SWCNT in A549 cells following $24 \mathrm{~h}$ exposure, however, morphological alterations in exposed cells observed in this study revealed that there were increased numbers of surfactant storing lamellar bodies. We therefore surmise that the increased presence of these lamellar bodies was a defensive response of these lung cells to SWCNT exposure and conclude that the protective function of the pulmonary surfactant following nanoparticle exposure warrants further investigation.

\section{Acknowledgements}

We sincerely thank Dr. David Cottell and his staff at the Electron Microscopy laboratory, University College Dublin, for expert technical assistance. This project was funded under the DIT Team Research Scheme (TERS). Eva Herzog is funded under the Technological Sector Research Strand I, Post Graduate R\&D Skills Programme. Benjamin Cottineau was supported by the DIT, SFI (Science Foundation Ireland) UREKA site FEATURE (Focus on Education in Analytical Techniques and Research Expertise).

\section{References}

Antonini, J.M., Reasor, M.J., 1994. Effect of short-term exogenous pulmonary surfactant treatment on acute lung damage associated with the intratracheal instillation of silica. Journal of Toxicology and Environmental Health 43, 85-101.

Antonini, J.M., McCloud, C.M., Reasor, M.J., 1994. Acute silica toxicity: attenuation by amiodarone-induced pulmonary phospholipidosis. Environmental Health Perspectives 102, 372-378.

Askin, F.B., Kuhn, C., 1971. The cellular origin of pulmonary surfactant. Laboratory Investigation 25, 260-268.

Casey, A., Davoren, M., Herzog, E., Lyng, F.M., Byrne, H.J., Chambers, G., in press. Probing the interaction of single walled carbon nanotubes within cell culture medium as a precursor to toxicity testing. Carbon.

Cui, D., Tian, F., Ozkan, C.S., Wang, M., Gao, H., 2005. Effect of single wall carbon nanotubes on human HEK293 cells. Toxicology Letters $155,73-85$.

Diabeté, S., Mülhopt, S., Paur, H.-R., Wottrich, R., Krug, H.F., 2002. In vitro effects of incinerator fly ash on pulmonary macrophages and epithelial cells. International Journal of Hygiene and Environmental Health 204, 323-326.

Dreher, K.L., 2004. Health and environmental impact of nanotechnology: toxicological assessment of manufactured nanoparticles. Toxicological Sciences 77, 3-5.

Emerson, R., Davis, G.S., 1983. Effect of alveolar lining material-coated silica on rat alveolar macrophages. Environmental Health Perspectives 51, 81-84.

Fehrenbach, H., 2001. Alveolar epithelial type II cell: defender of the alveolus revisited. Respiratory Research 2, 33-46.

Fiorito, S., Serafino, A., Andreola, F., Bernier, P., 2006. Effects of fullerenes and single-wall carbon nanotubes on murine and human macrophages. Carbon 44, 1100-1105.

Gregan, E., Keogh, S.M., Hedderman, T.G., Chambers, G., Byrne, H.J., 2003. Stokes/anti-Stokes Raman spectroscopy of HiPco single walled carbon nanotubes "Opto-Ireland 2002, Optics and Photonics Technologies and Applications". In: Blau, W.J., Donegan, J.F., Duke, A.F., MacCraith, B.D., McLaughlin, J.A., McMillan, N.D., O'Connor, G.M., O'Mongain, E., Toal, V. (Eds.), SPIE Proceedings 4876, p. 1149.

Gülden, M., Seibert, H., 2005. Impact of bioavailability on the correlation between in vitro cytotoxic and in vivo acute fish toxic concentrations of chemicals. Aquatic Toxicology 72, 327-337.

Hook, G.E., 1991. Alveolar proteinosis and phospholipidoses of the lungs. Toxicologic Pathology 19, 482-513.

Hook, G.E.R., 1993. Does pulmonary surfactant aid in defense of the lungs? Environmental Health Perspectives 101, 98-99. 
Huczko, A., Lange, H., Calko, E., Grubek-Jaworska, H., Droszez, P., 2001. Physiological testing of carbon nanotubes: are they asbestos-like? Fullerene Science and Technology 9, 251-254.

Hurt, R.H., Monthioux, M., Kane, A., 2006. Toxicology of carbon nanomaterials: status, trends, and perspectives on the special issue. Carbon 44, 1028-1033.

Jia, G., Wang, H., Yan, L., Wang, X., Pei, R., Yan, T., Zhao, Y., Guo, X., 2005. Cytotoxicity of carbon nanomaterials: single-wall nanotube, multi-wall nanotube, and fullerene. Environmental Science and Technology 39, 1378-1383.

Kagan, V.E., Tyurina, Y.Y., Tyurin, V.A., Konduru, N.V., Potapovich, A.I., Osipov, A.N., Kisin, E.R., Schwegler-Berry, D., Mercer, R., Castranova, V., Shvedova, A.A., 2006. Direct and indirect effects of single walled carbon nanotubes on RAW 264.7 macrophages: role of iron. Toxicology Letters, 165-88-165-100.

Lam, C.W., James, J.T., McCluskey, R., Hunter, R.L., 2004. Pulmonary toxicity of single-wall carbon nanotubes in mice 7 and 90 days after intratracheal instillation. Toxicological Sciences 77, 126-134.

Lieber, M., Smith, B., Szakal, A., Nelson-Rees, W., Todaro, G., 1976. A continuous tumor-cell line from a human lung carcinoma with properties of type II alveolar epithelial cells. International Journal of Cancer 17, 62-70.

Liebsch, H.M., Spielmann, H., 1995. Balb/c 3T3 cytotoxicity test. In: O'Hare, S., Atterwill, C.K. (Eds.), Methods in Molecular Biology, In Vitro Toxicity Testing Protocols, vol. 43. Humana Press Inc., NJ, pp. 177-187.

Monteiro-Riviere, N.A., Inman, A.O., 2006. Challenges for assessing carbon nanomaterial toxicity to the skin. Carbon 44, 1070-1078.

Monteiro-Riviere, N.A., Nemanich, R.J., Inman, A.O., Wang, Y.Y., Riviere, J.E., 2005. Multi-walled carbon nanotubes interactions with human epidermal keratinocytes. Toxicology Letters 155, 377-384.

Muller, J., Huaux, F., Lison, D., 2006. Respiratory toxicity of carbon nanotubes: How worried should we be? Carbon 44, 1048-1056.

Nicholas, T.E., 1996. Pulmonary surfactant: no mere paint on the alveolar wall. Respirology 1, 247-257.

Oberdörster, G., Oberdörster, E., Oberdörster, J., 2005. Nanotoxicology: an emerging discipline evolving from studies of ultrafine particles. Environmental Health Perspectives 113, 823-839.

Paradise, M., Goswami, T., in press. Carbon nanotubes-Production and industrial applications. Materials and Design.
Rouse, J.G., Yang, J., Barron, A.R., Monteiro-Riviere, N.A., 2006. Fullerene-based amino acid nanoparticles interactions with human epidermal keratinocytes. Toxicology in Vitro 20, 1313-1320.

Schimmelpfeng, J., Drosslemeyer, E., Hofheinz, V., Seidel, A., 1992. Influence of surfactant components and exposure geometry on the effects of quartz and asbestos on alveolar macrophages. Environmental Health Perspectives 97, 225-231.

Shvedova, A.A., Castranova, V., Kisin, E.R., Schwegler-Berry, D., Murray, A.R., Gandelsman, V.Z., Maynard, A., Baron, P., 2003. Exposure to carbon nanotubes material: assessment of nanotubes cytotoxicity using human keratinocyte cells. Journal of Toxicology and Environmental Health, Part A 66, 1909-1926.

Shvedova, A.A., Kisin, E.R., Mercer, R., Murray, A.R., Johnson, V.J., Potapovich, A.I., Tyurina, Y.Y., Gorelik, O., Arepalli, S., SchweglerBerry, D., Hubbs, A.F., Antonini, J., Evans, D.E., Ku, B.-K., Ramsey, D., Maynard, A., Kagan, V.E., Castranova, V., Baron, P., 2005. Unusual inflammatory and fibrogenic pulmonary responses to singlewalled carbon nanotubes in mice. American Journal of Physiology: Lung Cellular and Molecular Physiology 289, 698-708.

Smart, S.K., Cassady, A.I., Lu, G.Q., Martin, D.J., 2006. The biocompatibility of carbon nanotubes. Carbon 44, 1034-1047.

Stearns, R.C., Paulauskis, J.D., Godleski, J.J., 2001. Endocytosis of ultrafine particles by A549 cells. American Journal of Respiratory Cell and Molecular Biology 24, 108-115.

Thomas, K., Sayre, P., 2005. Research strategies for safety evaluation of nanomaterials, part I: evaluating the human health implications of exposure to nanoscale materials. Toxicological Sciences 87, 316-321.

Warheit, D.B., 2006. What is currently known about the health risks related to carbon nanotube exposures? Carbon 44, 1064-1069.

Warheit, D.B., Laurence, B.R., Reed, K.L., Roach, D.H., Reynolds, G.A. Webb, T.R., 2004. Comparative pulmonary toxicity assessment of single-wall carbon nanotubes in rats. Toxicological Sciences 77, 117-125.

Whitsett, J.A., Weaver, T.E., 2002. Hydrophobic surfactant proteins in lung function and disease. New England Journal of Medicine 347, 2141-2148.

Wirtz, H.R.W., Dobbs, L.G., 1990. Calcium mobilization and exocytosis after one mechanical stretch of lung epithelial cells. Science 250, 1266-1269.

Wörle-Knirsch, J.M., Pulskamp, K., Krug, H.F., 2006. Oops they did it again! Carbon nanotubes hoax scientists in viability assays. Nano Letters 6, 1261-1268. 